\title{
Analysis of internationalization trends in the construction industry with an overview on Croatian construction companies
}

DOI 10.2478/otmcj-2019-0006

Received December 28, 2018; accepted March 02, 2019

\begin{abstract}
Today's level of globalization and intensifying of competition have resulted in increased number of companies that aim to internationalize their business, and internationalization is gaining more and more significance among the research community. There are not only many perceived benefits of conducting business activities outside one's home country but also additional risks, challenges and barriers. Construction industry is specific in its nature as it is an extremely regulated profession. This presents an additional challenge to the construction companies seeking to internationalize their business. The goal of the paper is to analyze the current levels of internationalization on the global construction market and to gain insight into future trends, which are achieved by analyzing business data regarding the international construction sector and the data on international results of the Croatian construction companies. The paper first presents the development of the international construction market, followed by the report on the current state of the internationalization in the construction industry as well as on future trends. Finally, the paper presents an overview on the Croatian construction companies and their performance on the foreign markets and gives guidelines or potential growth strategies to participate on the foreign markets.
\end{abstract}

Keywords: internationalization, trend analysis, construction industry, Croatian construction companies

\footnotetext{
*Corresponding author: Lana Lovrenčić Butković, University of Zagreb, Faculty of Civil Engineering, Croatia; E-mail: llovrencic@grad.hr;

Matej Mihić, University of Zagreb, Faculty of Civil Engineering, Croatia
}

\section{Introduction}

Today's level of globalization and intensifying of the competition have resulted in increased number of companies that aim to internationalize their business (Morgan et al., 2012). Internationalization is a process of more extensive connection between the countries' markets and the process of expanding the technological, production, trade, traffic, communication and other relations between them (Leksikografski zavod Miroslav Krleža i Masmedija, 2011). In other words, the internationalization process is the expansion of economic activities outside the borders of the company's home country, which is reflected in quantitative changes that in turn lead to extensive geographical organization of economic activity (Rahimić and Podrug, 2013).

The construction industry follows the globalization trends, and internationalization is one of the largest interests of both scientific and practical research, which is evident from the fact that international sector of construction industry has for a long time been a topic of research and analysis for a large number of researchers (Crosthwaite, 1998; Bon and Crosthwaite, 2001; Ofori, 2003; Campbell and Verbeke, 1994). Due to its specifics and a large number of potential risks, internationalization presents a significant challenge for construction companies. The biggest problem for those construction companies that have decided to conduct their business activities on a foreign market is the fact that international business contains numerous risks (Zhi, 1995; Bing and Tiong, 1999; Han, 2001; Lee et al., 2011) and therefore requires that the companies have numerous competences to be able to deal with physical, technological, financial, legal, sociocultural and political issues presented by the internationalization.

The main goal of this paper is to present the development of the international construction sector and to give insight into the current practice and future trends of internationalization in the construction industry. The paper 
begins with a brief overview of the history of global construction market, followed by the analysis of the current state of the construction industry both worldwide and in Croatia and finishes with an analysis and estimation of future states and trends.

\section{Development of the global construction market}

The history of the global construction market and international business activities on foreign markets is tied to the nineteenth century, when UK construction companies started constructing railways outside of Great Britain (Linder, 1994). Linder (1994) has, in his book titled "Projecting capitalism: a history of the internationalization of the construction industry", divided the development of the global construction market into two phases.

The first phase is the time before World War II. In 1841, British contractors were constructing a railway line in France in the route from Paris to Rouen. After them, German construction companies have started building in the foreign markets, specifically a $1,930 \mathrm{~km}$ long railway line from Ankara to Baghdad. This time period was characterized by construction of ports, bridges and canals (for example, the Suez Canal, from 1859 to 1869). After World War I, American companies (especially in the oil industry) started to expand beyond the borders of USA. Infrastructure projects (energy and transportation), most prominently the ones for military purposes, dominated the international construction market for a long time (Strassmann and Wells, 1988).

The time after World War II constitutes the second phase of the development of the global construction market. The period was characterized by great destruction in Europe and in the Far East, followed by great investments in rebuilding the destroyed infrastructure and building stock. Finishing the restoration in their own country, the Japanese construction companies have turned to conquering foreign markets, first in the Far East and then in Africa (Stallworthy, 1985). The demand for new construction projects in the Third World countries would continue to increase.

USA construction companies dominated the global construction market shortly after the war, having participated in more than $90 \%$ of the large construction projects that were performed in that period (Günhan, 2010). Their domination was stopped by the appearance of Western European construction companies who could compete with the prices and with similar quality. By the end of 1970s, Japanese and South Korean companies started competing with both American and European companies.

In the 1980s, the extent of international construction market had dropped significantly due to the increase in oil prices and increase in the national debt of Third World countries. Additionally, local construction companies became more competitive and the governments had strengthened the barriers for entry to their national market for the foreign competitors (Günhan, 2010).

The developing countries are still attractive to foreign construction companies since they require infrastructure projects and they gladly cooperate with specialized companies from the developed countries. On the other hand, through globalizing the construction market, the opportunity was created for the local companies to compete on the international level (Han and Diekmann, 2001).

\section{Analysis of the global construction market}

The global economy is a result of changes in the business environment through time. It also creates and affects the environment and business conditions for all market sectors, including the construction industry. For example, the General Agreement on Tariffs and Trade (GATT) and the later creation of the World Trade Organization (WTO) have drastically changed the structure of the construction industry. By lowering international barriers, a chance was given to the construction companies from underdeveloped countries to participate on the markets of developed countries such as USA and European Union (EU) countries.

The economic crisis, which started in 2008 in USA and spread very fast to the rest of the world, made big changes in every sector. Its consequences are still felt especially in the construction industry. However, the latest data show that the global construction market is still an interesting arena. According to Information Handling Services (IHS) data, the value of global construction market in 2013 amounted to 8,194 billion USD (2.4\% more than in 2012) (IHS Markit, 2014). The report also estimated that construction output will grow with a rate of $4.9 \%$ a year in emerging markets in the period from 2013 to 2017. The estimation proved correct, since the value of the construction sector in 2017 was 10.6 trillion USD (Reuters, 2018), and compounded 5-year growth of $4.9 \%$ equals the value of 10.4 trillion USD.

For the purpose of this analysis, it would be interesting to see the global construction segment details. Table 1 shows that the largest value of the global construction 
Tab. 1: Values of the global construction market by its comprising sectors, 2013 (IHS Markit, 2014)

\begin{tabular}{lcc}
\hline & $\begin{array}{c}\text { Market size 2013 } \\
\text { (billions of USD) }\end{array}$ & $\begin{array}{c}\text { Real } \\
\text { growth (\%) }\end{array}$ \\
\hline Total & 8,194 & 2.4 \\
Residential & 2,997 & 2.6 \\
Infrastructure & 2,700 & 3.0 \\
Transportation & 1,256 & 2.3 \\
Public health & 191 & 1.3 \\
Energy & 1,253 & 4.1 \\
Non-residential structures & 2,497 & 1.5 \\
Office & 388 & 3.0 \\
Commercial & 557 & 2.5 \\
Institutional & 489 & -1.3 \\
Industrial & 1,063 & 1.7 \\
\hline
\end{tabular}

market was in the residential sector (2,997 billion dollars, $36.6 \%$ ), followed by infrastructure projects with a value of 2,700 billion USD (32.9\%) most of which is divided between transportation and energy. Finally, the nonresidential sector contributes with 2,497 billion USD or $30.5 \%$. All three sectors have approximately similar market share; however, infrastructure is expected to have the largest growth, due to growing infrastructure needs in both developed and developing countries.

Table 1 shows the growth of the construction industry by sectors. For the purpose of this paper, it is also important to show growth independently for emerging markets and for international construction activity. According to Global Construction Outlook (IHS Markit, 2014), construction output growth in the period 2018-2022 in emerging markets will average $4.3 \%$ a year. The global construction industry is expected to reach an estimated $\$ 10.5$ trillion by 2023 (ReportLinker, 2017). Globally, the International Monetary Fund (IMF) in its World Economic Outlook report has estimated that the share of the construction industry composes $15 \%$ of the world GDP (International Monetary Fund, 2014).

As for the international construction activity, the Engineering News Record (ENR) publishes a yearly list of 250 largest international construction companies (both public and private). The list is based on the income from projects outside the home country of the construction company. The companies listed in the ENR report in August 2018 have achieved a total income of 482.40 billion USD in 2017 from projects outside their home countries, which is 3.1\% higher than in 2016. Those same companies also reported 1.034 billion USD in revenue from domestic projects (The Engineering News-Record, 2018), which means that their income from the foreign markets is $31.81 \%$. Table 2 shows rankings and construction company name.
Tab. 2: Twenty largest international construction companies based on the international income in 2017 (The Engineering News-Record, 2018)

\begin{tabular}{|c|c|c|c|}
\hline \multicolumn{2}{|c|}{ RANK } & \multirow[b]{2}{*}{ Construction company } & \multirow[b]{2}{*}{ Country } \\
\hline 2018 & 2017 & & \\
\hline 1 & 1 & ACS Group, Madrid & Spain \\
\hline 2 & 2 & HOCHTIEF AG, Essen & Germany \\
\hline 3 & 3 & $\begin{array}{l}\text { China Communications Construction } \\
\text { Group Ltd., Beijing }\end{array}$ & China \\
\hline 4 & 4 & $\begin{array}{l}\text { VINCI, Rueil-Malmaison, Hauts-de- } \\
\text { Seine }\end{array}$ & France \\
\hline 5 & 9 & STRABAG SE, Vienna & Austria \\
\hline 6 & 7 & TechnipFMC, London & UK \\
\hline 7 & 6 & Bouygues, Paris & France \\
\hline 8 & 11 & $\begin{array}{l}\text { China State Construction Eng. Corp. } \\
\text { Ltd., Beijing }\end{array}$ & China \\
\hline 9 & 8 & Skanska AB, Stockholm & Sweden \\
\hline 10 & 10 & $\begin{array}{l}\text { Power Construction Corp. of China, } \\
\text { Beijing }\end{array}$ & China \\
\hline 11 & 13 & Ferrovial, Madrid & Spain \\
\hline 12 & 5 & Bechtel, San Francisco, Calif. & USA \\
\hline 13 & 16 & Fluor Corp., Irving, Texas & USA \\
\hline 14 & 23 & $\begin{array}{l}\text { China Railway Construction Corp. } \\
\text { Ltd., Beijing }\end{array}$ & China \\
\hline 15 & 18 & Salini Impregilo SPA, Milan & Italy \\
\hline 16 & 14 & $\begin{array}{l}\text { Hyundai Engineering \& Construction } \\
\text { Co. Ltd., Seoul }\end{array}$ & $\begin{array}{l}\text { South } \\
\text { Korea }\end{array}$ \\
\hline 17 & 21 & China Railway Group Ltd., Beijing & China \\
\hline 18 & 19 & $\begin{array}{l}\text { Consolidated Contractors Group, } \\
\text { Athens }\end{array}$ & Greece \\
\hline 19 & 22 & Tecnicas Reunidas, Madrid & Spain \\
\hline 20 & 15 & Petrofac Ltd., Jersey, Channel Islands & UK \\
\hline
\end{tabular}

Out of the 20 largest international construction companies, 12 of them are from Europe (60\%), five are from China, two from USA and one from South Korea. The Europe-based companies have achieved an income of approximately 194 billion USD from the foreign markets. They are followed by the companies based in USA ( 40.4 billion USD), South Korea (approximately 22 billion USD), China (approximately 19 billion USD) and Brazil (9.9 billion USD) (The Engineering News-Record, 2018).

\section{Trends in international construction}

Global construction industry's future looks optimistic with investment opportunities in all the following three sectors: residential, non-residential and infrastructure. A report titled Growth Opportunities in the Global 
Construction Industry (ReportLinker, 2017) states that "The global construction industry is expected to reach an estimated $\$ 10.5$ trillion by 2023 , and it is forecast to grow at a Compound Annual Growth Rate (CAGR) of 4.2\% from 2018 to 2023.” The need for construction work in all sectors can be extrapolated from the fact that "the population of the world's urban areas is increasing by 200,000 people per day, all of whom need affordable housing as well as social, transportation and utility infrastructure" (World Economic Forum, 2016).

However, it is very difficult to identify trends in the global construction industry. At the end of the twentieth century, numerous experts anticipated that the international construction sector will continue to grow, but, however, the global crisis in 2008 had severely affected the construction industry and its impact is seen even 10 years later. However, since 2013, the data started to suggest that the economy had begun to recover. After a longer recession, new projects began to emerge and more and more funds became available for maintaining existing and constructing new infrastructure projects.

The research conducted by KPMG International in 2013, on the sample of 165 construction companies, had shown a generally positive attitude and optimism in the construction industry (KPMG International, 2014). Furthermore, based on the data collected by IHS (2014), they predicted that the value of global construction market will rise for around 3.8\% per year in period 2017-2022. This growth should be lead by the Asian and Pacific markets with expected growth of 5.8\% (Figure 1). China will also continue its growth, mostly in the central and western provinces.

In the last 5-year period (2012-2017), the South American market had the most significant growth, due to the reconstruction of the Suez Canal and due to the Olympic Games that took place in Brazil in 2016. In the same time, the Eastern European market had one of the smallest growths, dominated by the Russian market because of the preparations for the football World Cup in 2018.

Based on the assessments of IHS, the perspective growth in the following 5-year period is that of a slow growth in all the regions. Asia-Pacific region will stay in the lead, but their growth will decrease to around 5.3\%. The growth value of South American and North American markets will be sharply decreased. Growth in Africa and Middle East will decrease as well; however, only slightly. Only the markets of Western and Eastern Europe will see the recovery after a long period of recession and are expected to achieve an increase in the growth of value of the construction sector.

Whether the market will grow or decrease depends on several factors. It is well known that the anticipated

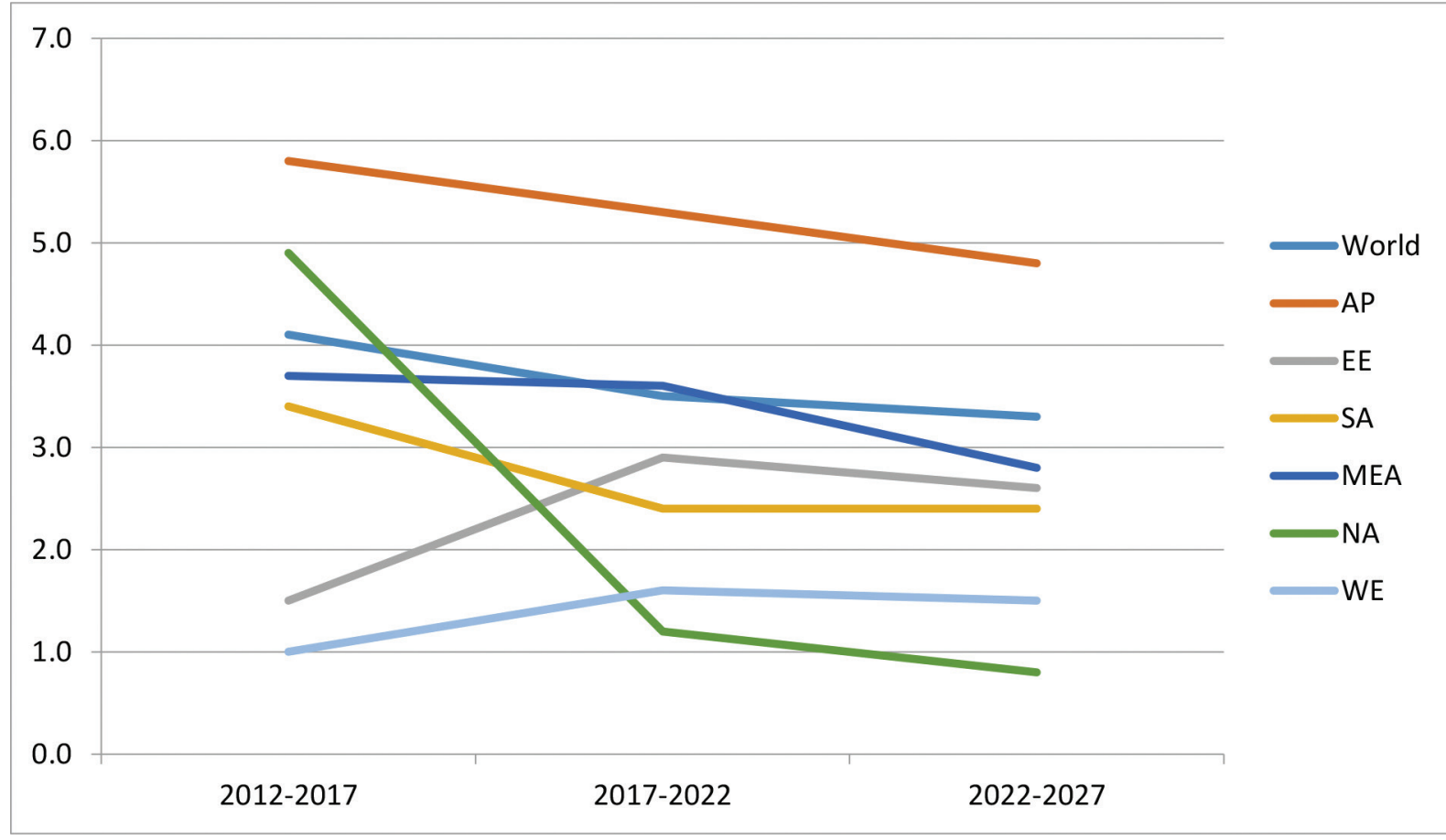

* $\mathrm{AP}=$ Asia-Pacific, $\mathrm{EE}=$ Eastern Europe, $\mathrm{SA}=$ South and Central America, $\mathrm{MEA}=$ Middle East and Africa, NA $=$ North America, $\mathrm{WE}=$ Western Europe

Fig. 1: Growth of values of global construction markets per region (IHS Markit, 2014). 
growth of construction companies strongly depends on national infrastructure projects, since the governments are still the leading market drivers of the construction sector with around $66 \%$ market share. However, there are numerous other factors that can initiate growth of the international construction sector, as shown in Figure 2.

Next to the main drivers of the construction market (government's infrastructure projects), other significant drivers are global economic growth, urbanization and access to new energy sources (especially in countries such as Brazil, Russia, India and China, and other countries with developing economies). As a consequence of urbanization and populating larger cities, potential infrastructure objects such as water and electrical energy distribution networks, telecommunications, sewage, roads and bridges need to be constructed or improved.

To better answer to the drivers of the construction industry, the construction companies develop their own strategies. By analyzing the business strategy plans in the following years, KPMG's research has shown that $47 \%$ of the respondents plan entering foreign markets as a growth strategy, whereas $44 \%$ are planning to enter new sectors of the industry (Figure 3) (KPMG International, 2014).

Figure 3 shows that as much as $78 \%$ of the leading international construction companies plan their development on existing markets (both foreign and domestic). A positive indicator of the construction market's growth is the significant number of companies that plan to enter new markets.

Multinational construction companies find African countries, USA, Canada and Far East as most popular regions to expand their business (KPMG International, 2014). New perspective sectors for the construction companies, on the other hand, are energy industry (power plant construction), mining, water management projects, railway and other transportation projects. Asian markets have large infrastructure requirements, such as the construction of roads and bridges.

To enter new markets and new sectors, it is not enough to simply have the courage and determination. Construction companies need to be aware that operating in a demanding international construction industry requires new knowledge and skills.

For the past few decades, engineering and construction companies have focused mainly on effective project management to ensure that construction projects meet deadlines and budget and to improve quality. KPMG's research conducted in 2017 (KPMG International, 2017) shows that after a period of focusing on project management, construction companies have to turn on reimagining governance, people and technology at the organizational level. KPMG has developed an integrated framework that reimagines governance and controls, people and technology around three key principles that should drive this step-change performance improvement (Figure 4).

Three key steps to closing the performance gap for construction companies are (KPMG International, 2017) as follows:

- evolve by rationalizing governance and controls,

- innovate through investment in technology, and

- integrate by optimizing human performance.

Not unlike in most other industries, technology lies at the heart of the future engineering and construction company. Engineering and construction are competitive, thin-margin businesses, where companies have to fight hard to win every new piece of work and then deliver highly complex projects. Precisely because of that, the construction companies should strive for technological developments.

Digital revolution, which started in the late twentieth century, took part in making the world a smaller place and in enabling internationalization. Improvements in

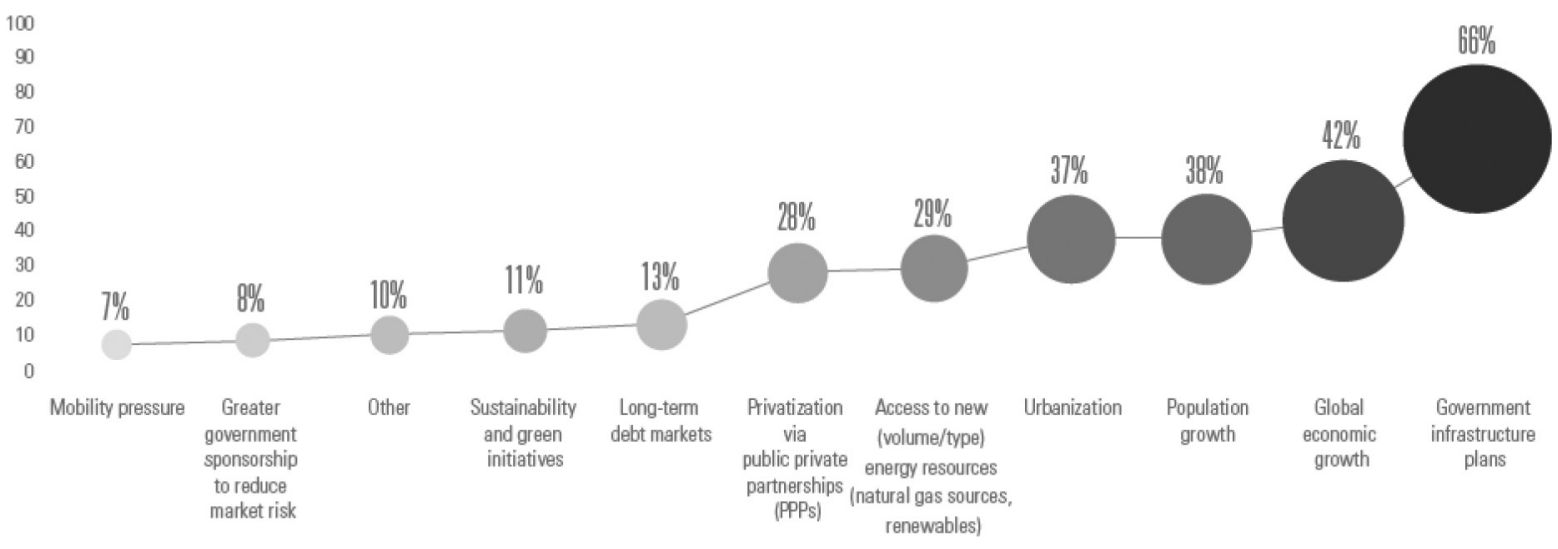

Fig. 2: Primary drivers of the international construction market (KPMG International, 2014). 


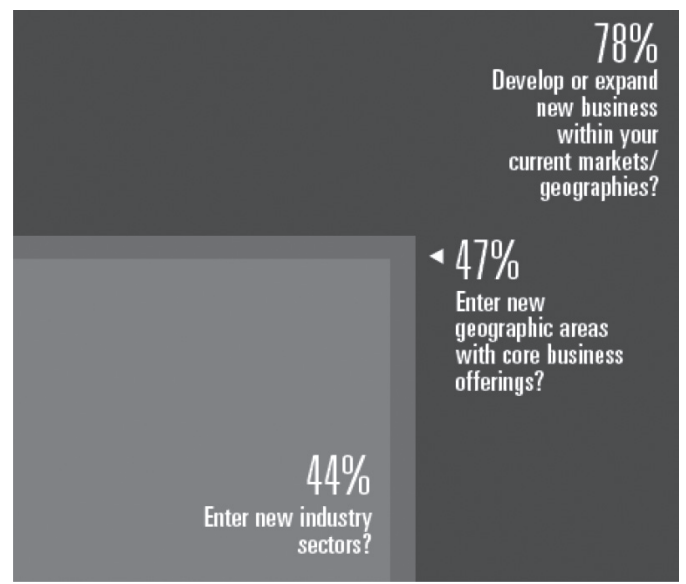

Fig. 3: Growth strategies of international construction companies (KPMG International, 2014).

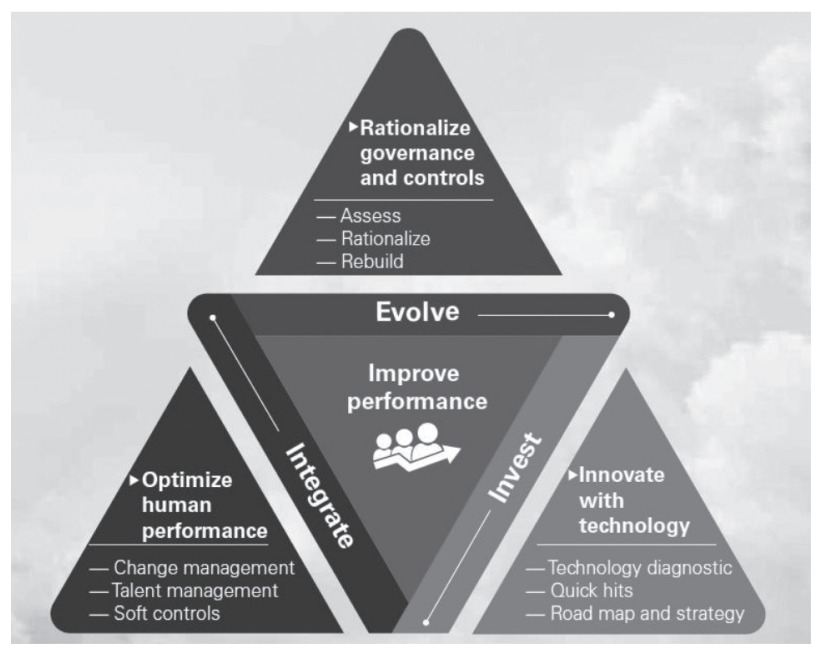

Fig. 4: Three steps to closing the performance gap (KPMG International, 2017).

information technologies benefited numerous industries by lessening the barriers to entering foreign markets, increasing productivity, facilitating automatization and improving knowledge transfer and information availability, among others.

However, construction industry, unlike most other production industries, is traditionally slow to implement new technologies, not because it does not want to but rather due to its specific nature. For example, there is a lack of innovation and delayed adoption since the benefits of research and development are long term and costs are immediate (World Economic Forum, 2016). This is in contrast with the project-driven approach prevalent in the industry. Another similar issue with the same underlying cause is the lack of knowledge transfer from one project to another. Finally, the third reason why implementation of new technologies is slower in the construction industry is the lack of talented workers who would drive the change within the industry (World Economic Forum, 2016). Therefore, a large untapped potential exists in the construction industry for increased productivity and by extension profit, improved industry perception and further development.

A technology with most potential for improving the construction industry is Building Information Modeling (BIM) and not just by itself but also as a key enabler and facilitator of other technologies (World Economic Forum, 2016). BIM is central to the digitalization process of the construction industry and enables "new functionalities along the entire value chain, from the early design phase to the very end of an asset's life cycle at the demolition phase” (World Economic Forum, 2016).

\section{Croatian construction industry in the context of international construction industry}

In the decades before the Homeland war in Croatia, Croatian construction companies were achieving significant income from the foreign markets because they could guarantee successful realization of even the most complex construction projects due to their experience in constructing all types of structures. In 1990, just before the war, the companies had completed construction works valued at 320 million USD on the European, Asian and African markets. That value was achieved again in 2007.

However, there is a significant obstacle to analyzing in detail the results of Croatian construction companies on foreign markets. Since May 2008, the Croatian Bureau of Statistics does not track the data on conducted construction works by the construction companies, and an alternative source was needed. Fortunately, the Croatian Financial Agency (FINA), which is a national body for financial information and services, collects a multitude of data relevant for this research. The data used include the list of 100 highest grossing companies registered for construction works in Croatia, their total income and their income from international markets. The summarized data are presented in Table 3 and are explained in the following paragraphs. Table 4, on the other hand, presents the industry averages.

Data from Table 3 shows the total income of the 100 largest grossing construction companies in Croatia, their total income from the foreign markets, number of 
Tab. 3: Foreign market performance of the 100 largest grossing construction companies (author calculations based on the data from FINA (2018) and Poslovna Hrvatska (2018))

\begin{tabular}{|c|c|c|c|c|c|}
\hline Year & 2013 & 2014 & 2015 & 2016 & 2017 \\
\hline Total income (top 100)* & 2,597 & 2,584 & 2,610 & 2,755 & 3,026 \\
\hline Income from the foreign markets (top 100$)^{\star}$ & 110 & 154 & 172 & 188 & 238 \\
\hline $\begin{array}{l}\text { Number of construction companies that have achieved income } \\
\text { from the foreign markets (out of top 100) }\end{array}$ & 26 & 32 & 30 & 34 & 35 \\
\hline Percentage of the income from the foreign markets (top 100) & 4.22 & 5.96 & 6.57 & 6.86 & 7.86 \\
\hline
\end{tabular}

*In million USD.

Tab. 4: Industry average total and foreign performance (author calculations based on the data from FINA (2018) and Poslovna Hrvatska (2018))

\begin{tabular}{|c|c|c|c|c|c|}
\hline Year & 2013 & 2014 & 2015 & 2016 & 2017 \\
\hline Industry average total income (in USD) & $434,197.53$ & $520,385.80$ & $474,027.78$ & $436,697.53$ & $521,496.91$ \\
\hline Industry average income from the foreign markets (in USD) & $5,756.17$ & $7,746.91$ & $6,774.69$ & $14,845.68$ & $19,490.74$ \\
\hline $\begin{array}{l}\text { Percentage of the income from the foreign markets } \\
\text { (industry average) }\end{array}$ & 1.33 & 1.49 & 1.43 & 3.40 & 3.74 \\
\hline
\end{tabular}

companies that have exported their construction activities and the percentage of income from the foreign markets, all for the last five available years (2013-2017).

The data corroborate some of the previous statements that the crisis has passed and that the volume of construction work is on the rise with the volume rising from 2,597 million USD in 2013 to 3,026 million USD in 2017 (16.52\% increase). Income from the foreign markets has seen an even steeper continuous rise from 110 million USD to 238 million USD, which is a growth of $116.36 \%$ in only 5 years. The downside is that it still accounts for only $7.86 \%$ of the total income and that only 35 (up from 26 in 2013) out of the 100 largest grossing companies have participated on the foreign market in 2017.

Since the companies can be registered for more than one commercial activity, the values for income in some cases can include income from sources other than construction work. However, it is only extremely evident for two companies, both of which are operators of Croatian highways. Most of their income comes from the tolls, they do not have any export activities and they therefore worsen the percentage of the income from the foreign markets.

Industry average paints an even bleaker picture. As the data presented in Table 4 show, in 2013 the average income from the foreign markets was only 5,756.17 USD. Average income from export has grown 3.38 times in the five following years to nearly 20,000 USD but percentagewise it still accounts for only $3.74 \%$ of the total income. Although the Croatian market has started to recover, the process would be faster if the companies had focused on markets less affected by the recession.
Assisting in the export of construction activities is therefore one of the most significant components in the recovery of the Croatian market (Hrvatska gospodarska komora, 2013), because the construction companies have enough knowledge and experience in constructing complex objects to be able to compete on the global market. The companies' management states that one of the most significant issues is the lack of a strong support from the Croatian Bank for Reconstruction and Development (HBOR) in their export activities, especially in ensuring bid and performance bonds. However, HBOR does have programs for financial aid to raise the competitive strength of the construction industry. The first program is financing working capital and financing investments; the second is ensuring bonds for export activities; and the third is issuing insurance for export claims and insurances that protect the constructors from political and commercial risks (Hrvatska gospodarska komora, 2013). Experts on the other hand believe that HBOR's potentials need to be expanded, because it does not have such strength and financial capital to successfully follow Croatian construction companies that are willing and able to compete on the demanding international market. Furthermore, an additional barrier is the higher price of the workforce. Croatian construction worker is $20 \%$ more expensive on the foreign market when compared to domestic market (Hrvatska gospodarska komora, 2013).

The question is how and in what ways can the Croatian construction companies return to the global construction markets and how to become competitive on the extremely demanding global market. Some of the 
potential ways are presented in Figure 5 (Lovrencic Butkovic and Katavic, 2014).

A possible model of recovery for the construction sector could be through joining construction companies into clusters or consortiums, at least on a project-byproject basis. The companies could also become more competitive on the global market through larger investments into research and development and innovating their products and services. Global market not only does have high competitiveness level but is also open and diversified especially in terms of cooperation and in finding niches or specialized production.

Therefore, expanding to foreign markets is more and more represented as a survival strategy for all companies, especially those in the construction industry. Experience has shown that construction companies answer the demands of competitive environments and more sophisticated demands by using strategies such as acquisitions, mergers, joint ventures, licensing and development of products and/or services (Gunhan and Arditi, 2005). Presence on the foreign markets can also be established by founding a subsidiary or through merging with local companies (Pheng and Hongbin, 2003).

Based on the results of research conducted in 2014, the most common way of appearing on foreign markets for Croatian construction companies is as a joint venture (Lovrenčić Butković, 2016). Today, it is almost unimaginable for a construction company to conduct business on a foreign market without the help of other companies or banks. This strategy is one of the specific forms of joining the companies through merging capital on a joint project or endeavor, and it is often used by

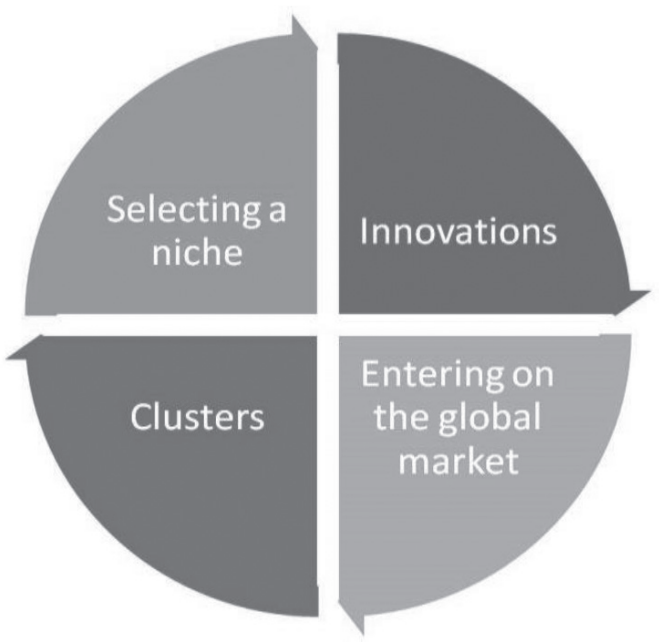

Fig. 5: Potential ways of recovering the Croatian construction industry (Lovrencic Butkovic and Katavic, 2014). companies to penetrate into foreign markets through joint ventures with a local company (Bahtijarević-Šiber and Sikavica, 2001).

The results of the aforementioned research have shown that other strategies for conducting business on foreign markets are through founding subsidiaries (part of the company that conducts business activities in a foreign country but does not have its own legal status), followed by independent appearance on a construction project and finally through founding another company, whether on their own or in cooperation with another company (Lovrenčić Butković, 2016).

\section{Conclusion}

It is unquestionable that a contemporary company needs to focus its business operations on foreign markets to achieve long-term competitiveness. Considering the many specifics of the construction industry and consequently the construction companies, stepping out into foreign markets presents a significant challenge.

Conclusions of numerous research studies, as well as this paper, are that after several years of crisis in the construction industry, a recovery is in sight and that new markets offer numerous possibilities to those construction companies that are willing to focus their strategy on internationalizing their business operations. The paper mentioned some of the possible growth strategies such as developments on the existing markets, entering a new sector or entering new markets. However, to compete in the international markets, it is necessary to implement new marketing strategies, new construction technologies and to educate the workforce. From when Croatia became a member of the EU, numerous foreign construction companies can equally participate on its market, making the need for Croatian construction companies to expand to other markets more significant and urgent.

Nevertheless, to intensify the export of construction services abroad, a more active participation of banks in crediting export activities is needed, as well as a stronger diplomatic support. Exporting construction services could further facilitate the export of other goods or services to the available markets (Hrvatska gospodarska komora, 2013). The question remains whether the Croatian construction companies are ready, willing and able to accept the challenge and to take part in the global construction market. 


\section{References}

Bahtijarević-Šiber, F. and P. Sikavica, Leksikon menedžmenta. 2001: Masmedia.

Bing, L., \& Tiong, R. L. K. (1999). Risk Management Model for International Construction Joint Ventures. Journal of Construction Engineering and Management, 125(5), pp. 377-384.

Bon, R., \& Crosthwaite, D. (2001). The future of international construction: some results of 1992-1999 surveys. Building Research \& Information, 29(3), pp. 242-247.

Campbell, A. J., \& Verbeke, A. (1994). The globalization of service multinationals. Long Range Planning, 27(2), pp. 95-102.

Crosthwaite, D. (1998). The internationalization of British construction companies 1990-96: an empirical analysis. Construction Management and Economics, 16(4), pp. 389-395.

FINA. Financial Agency - Croatian companies annual reports. 2018 [cited 2018. 18.12.]; Available from: https://www.fina.hr/ informacije-o-poslovanju-poslovnih-subjekata1.

Gunhan, S., \& Arditi, D. (2005). Factors Affecting International Construction. Journal of Construction Engineering and Management, 131(3), pp. 273-282.

Günhan, S. (2010). Foreign Market Entry Decision Model for Construction Companies. VDM Publishing, Saarbrücken.

Han, S. H. (2001). A risk-based entry decision model for international projects. KSCE Journal of Civil Engineering, 5(1), pp. 87-96.

Han, S. H., \& Diekmann, J. E. (2001). Approaches for Making Risk-Based Go/No-Go Decision for International Projects. Journal of Construction Engineering and Management, 127(4), pp. 300-308.

Hrvatska gospodarska komora. (2013). Analiza izvoznih mogućnosti hrvatskog graditeljstva. Hrvatska gospodarska komora, Zahreb.

IHS Markit, IHS Economics Global Construction Outlook: Executive Summary. 2014.

International Monetary Fund, The World Economic Outlook. 2014.

KPMG International. (2014). Global Construction Survey 2013: Ready for the next big wave? Available at http://www.kpmg. com/Global/en/IssuesAndInsights/ArticlesPublications/ global-construction-survey/Documents/global-construction-survey-2013-v2.pdf.

KPMG International. (2017). Global Construction Survey 2017: Make it, or break it. Available at https://home.kpmg.com/xx/en/ home/insights/2017/10/global-construction-survey-make-itor-break-it.html.

Lee, S.-H., Jeon, R. K., Kim, J. H., \& Kim, J. J. (2011). Strategies for Developing Countries to Expand Their Shares in the Global
Construction Market: Phase-Based SWOT and AAA Analyses of Korea. Journal of Construction Engineering and Management, 137(6), pp. 460-470.

Leksikografski zavod Miroslav Krleža i Masmedija. (2011). Ekonomski leksikon, Second edition edn. Leksikografski zavod Miroslav Krleža i Masmedija, Zagreb.

Linder, M. (1994). Projecting Capitalism: A History of the Internationalization of the Construction Industry. GREENWOOD Publishing Group Incorporated, Westport, CT, USA.

Lovrencic Butkovic, L. and M. Katavic, Marketing Perspectives for the Construction Sector. Economic and Social Development: Book of Proceedings, 2014: p. 175.

Lovrenčić Butković, L. (2016). Utjecaj ključnih činitelja uspjeha pri odabiru poslovne strategije nastupa građevinskih poduzeća na inozemnim tržištima. University of Zagreb. Faculty of Economics and Business.

Morgan, N. A., Katsikeas, C. S., \& Vorhies, D. W. (2012). Export marketing strategy implementation, export marketing capabilities, and export venture performance. Journal of the Academy of Marketing Science, 40(2), pp. 271-289.

Ofori, G. (2003). Frameworks for analysing international construction. Construction Management and Economics, 21(4), pp. 379-391.

Pheng, L. S., \& Hongbin, J. (2003). Internationalization of Chinese Construction Enterprises. Journal of Construction Engineering and Management, 129(6), pp. 589-598.

Poslovna Hrvatska. Pregled poslovanja poslovnih subjekata. 2018 [cited 2018. 18.12.]; Available from: http://www. poslovnahrvatska.hr.

Rahimić, Z., \& Podrug, N. (2013). Međunarodni menadžment. Ekonomski fakultet u Sarajevu, Sarajevo.

ReportLinker, Growth Opportunities in the Global Construction Industry. 2017.

Reuters. Global Construction Market 2018; Expected To Drive a Galloping Growth to US\$12.7 trillion By 2022. 2018 [cited 2019 22.02.]; Available from: https://www.reuters.com/ brandfeatures/venture-capital/article $?$ id $=48295$.

Stallworthy, E. A. (1985). International Construction and the Role of Project Management. Kharbanda, O. P. (ed.), Gower, Aldershot, Hants, England; Brookfield, VT, U.S.A.

Strassmann, W. P., \& Wells, J. (1988). The Global construction industry: strategies for entry, growth, and survival. Unwin Hyman, London.

The Engineering News-Record, The Top 250 International Contractors. 2018.

World Economic Forum. (2016). Shaping the Future of Construction: A Breakthrough in Mindset and Technology. World Economic Forum, Geneva, Switzerland.

Zhi, H. (1995). Risk management for overseas construction projects. International Journal of Project Management, 13(4), pp. 231-237. 